CELLULOSE (ISSN: 0969-0239) 22(3): 1883-1891 (2015).

DOI: 10.1007/s10570-015-0587-1

\title{
The potential use of cellophane test strips for the quick determination of food colours
}

\author{
Mária Pávai, Tamás Szabó, and András Paszternák* \\ Institute of Materials and Environmental Chemistry, Research Centre for Natural Sciences, \\ Hungarian Academy of Sciences \\ 1117 Budapest, Magyar tudósok körútja 2., HUNGARY \\ *Corresponding author: paszternak.andras@ttk.mta.hu, Tel./Fax: +36-1-382-6988
}

\section{ABSTRACT}

Concern on different food colours has a rising tendency in the last decades. Many times the labelled ingredients of a food product don't reflect the real composition. To expose products adulterated by synthetic colorants or to check non-packed foods (like ice cream, fruit drinks sold on the streets) fast and cheap methods are needed. Quick and in situ determination of the colouring agents can be achieved with high sensitivity and reproducibility by using the presented test method based on visual and/or optical characterisation of the cellophane test strip. The selectivity of cellophane to synthetic dyes is used to distinguish natural and synthetic food colours in beverages and foods.

KEYWORDS: cellophane, food colour, natural dye, azo-dye, optical characterisation, test strip 


\section{Importance of food colour detection}

Consumer acceptance of a food product is largely affected by its colour, indicating that food colour is an important attribute of food quality (Shen et al. 2014). The technological functions that colours perform include: offsetting colour loss caused by processing; enhancing colour already present in the food; and protecting flavours and vitamins that may be light sensitive (FSANZ 2008).

The presence of synthetic dyes in food shows a potential health risk, as several diseases (allergy, asthma, hyperactivity and even cancer) are directly linked to the use of these colours (Aguilar 2009-1). In the last decade intensive debate has been formed around the health impact of the synthetic dyes (Aguilar 2009-2) influencing many times also the law-making processes. The lists of permitted food colours vary from country to country. As an example (Yoshioka and Ichihashi 2008) azorubine, quinoline yellow and patent blue V are nonpermitted in USA and Japan, but are permitted and frequently used in EU countries.

\section{Methods for food colour detection}

Popular methods (EC 2013) that have been used for detection of synthetic food dyes include thin layer chromatography, high performance liquid chromatography (Kucharska and Grabka 2010), capillary electrophoresis and nuclear magnetic resonance (Komissarchik and Nyanikova 2014). Chemical reactions to detect the presence of natural or synthetic food colours are also available in the literature (FSSAI 2012). These methods, in most of the cases, need laboratory background and are not accessible directly to customers, in contrast to the cellophane test strip method described here. 
Cellophane, which is a thin, transparent, regenerated cellulose film produced from sodium cellulose xanthate (Laity et al. 2000), has been an important industrial material for many years. It is a well-known hydrophilic, water insoluble natural polymer - this property is related to its crystallinity and the intermolecular hydrogen bonding between its hydroxyl groups (Tome et al. 2011; Canas et al. 2002).

It is used as packaging material for food and confectionary products (candies, cheese and baked goods), and due to its good mechanical properties and hydrophilicity it finds applications in industry (membranes for batteries) (Tome et al. 2011; Beach et al. 2000), and medicine (semipermeable membranes for haemodialysis - since cellophane allows the diffusion of ions and low molecular weight solutes but it does not permit the diffusion of proteins or high molecular weight macromolecules) (Tome et al. 2011; Canas et al. 2002).

Although nowadays its pre-eminence in the packaging industry has been largely superseded by the oriented polypropylene film, cellophane still has special uses due to its physical properties, which confer advantages compared to other polymers (Laity et al. 2000).

Compared to cellulose, it has a differentiated 'skin-core' layer structure, with relatively thin, dense skin on both side of the thicker, porous core (Fig. 1A). The swelling of cellophane in water is well known, reaching equilibrium within a period of 2 hours, with no further changes in dimensions. The thickness of the cellophane is $26 \pm 1 \mu \mathrm{m}$ as received, $68 \pm 2 \mu \mathrm{m}$ fully swollen with water (Laity et al. 2000).

Cellophane is transparent both to ordinary and UV-light; it exhibits the anisotropic properties of cellulose due to its two optical axes and it has excellent dielectric properties. Per se it is not 
porous, but it contains numerous capillaries, which during the swelling are filled with solution (Evans 1964).

The goal of the present study is to build a quick, qualitative food colour test method using the selective food colours colouring effect on cellophane. Main application area of such test method can be the exposition of products adulterated by synthetic colorants or the in situ check of non-packed foods, like ice cream or fruit drinks sold on the streets. The comparison of natural and synthetic food colours is discussed.

\section{EXPERIMENTAL}

\section{Preparation of the test strip}

Cellophane sheet (Sigma-Aldrich, Budapest, Hungary) is cut to $1 \mathrm{x} 2 \mathrm{~cm}^{2}$ pieces and it is used without further cleaning or surface modification. The manipulation of the test strip is performed with tweezers to avoid the contamination of the sample surface.

\section{Primary and natural food colours}

Primary food colours (Table 1.) are used as received (Szilas Aroma Ltd., Kerepes, Hungary).

Table 1. - Primary food colours

\begin{tabular}{|c|c|c|c|}
\hline Name & $\begin{array}{c}\text { E- } \\
\text { number }\end{array}$ & $\begin{array}{c}\text { Abbreviatio } \\
\mathbf{n} \text { in the text }\end{array}$ & Chemical name \\
\hline tartrazine & $\mathbf{E 1 0 2}$ & Yellow & $\begin{array}{c}\text { trisodium (4E)-5-oxo-1-(4-sulfonatophenyl)-4- } \\
\text { [(4-sulfonatophenyl)hydrazono]-3- } \\
\text { pyrazolecarboxylate }\end{array}$ \\
\hline azorubine & $\mathbf{E 1 2 2}$ & Red & $\begin{array}{c}\text { disodium 4-hydroxy-2-[(E)-(4-sulfonato-1- } \\
\text { naphthyl)diazenyl]naphthalene-1-sulfonate }\end{array}$ \\
\hline $\begin{array}{c}\text { patent blue } \\
\text { V }\end{array}$ & E134 & Blue & $\begin{array}{c}\text { sodium or calcium salt of [4-( } \text {-(4- } \\
\text { diethylaminophenyl)-5-hydroxy-2,4- } \\
\text { disulfophenylmethylidene)-2,5-cyclohexadien- } \\
\text { 1-ylidene] diethyl ammonium hydroxide inner } \\
\text { salt }\end{array}$ \\
\hline $\begin{array}{c}\text { mixture of } \\
\text { tartrazine } \\
\text { and patent } \\
\text { blue V }\end{array}$ & - & Green & \\
\hline
\end{tabular}


Natural food colours (Table 2.) are processed in our laboratory. $1 \mathrm{~g}$ of minced curcuma (Kotányi Hungária Ltd., Budapest, Hungary) is mixed with $25 \mathrm{ml}$ Mili-Q water and it's used after 10 minutes of sedimentation. The red paprika powder (Kotányi Hungária Ltd., Budapest, Hungary) is processed in the same way. Beetroot is grated; $20 \mathrm{~g}$ of grated beetroot is mixed with 50 g Milli-Q water (Pourrat et al. 1983; Rey et al. 2005). The Milli-Q water dissolves the anthocyanins from the grated beetroot in approximate 10 minutes. The mixture is filtered, and the anthocyanin solution is kept in refrigerator. $\beta$-carotene water extract (Desobry et al. 1998) from carrot is obtained in the same way as the beetroot extract. $10 \mathrm{~g}$ granulated sugar (Magyar Cukor Ltd., Budapest, Hungary), is used for the preparation of the caramelised sugar (Jiang et al. 2008). The melted sugar is dissolved in $20 \mathrm{ml}$ Milli-Q water.

\section{Table 2. - Natural food colours}

\begin{tabular}{|c|c|c|c|}
\hline Name & E-number & Source & Chemical name \\
\hline curcumin & E100 & curcuma & $\begin{array}{c}\text { (1E,6E)-1,7-Bis(4-hydroxy-3- } \\
\text { methoxyphenyl)-1,6-heptadiene-3,5-dione) }\end{array}$ \\
\hline capsorubin & E160c & red paprika & $\begin{array}{c}\left.\text { all-E, } 3 S, 3^{\prime} S, 5 R, 5^{\prime} R\right)-3,3^{\prime} \text {-dihydroxy- } \kappa, \kappa- \\
\text { carotene- } 6,6^{\prime} \text {-dione }\end{array}$ \\
\hline betanin & E162 & beetroot & $\begin{array}{c}\text { 4-(2-(2-carboxy-5-(beta-D- } \\
\text { glucopyranosyloxy)-2,3-dihydro-6-hydroxy- } \\
\text { 1H-indol-1-yl)ethenyl })-2,3 \text {-dihydro- }(S- \\
\left.\left(R^{*}, R^{*}\right)\right)-2,6 \text {-pyridinedicarboxylic acid }\end{array}$ \\
\hline$\beta$-carotene & E160a & carrot & $\begin{array}{c}\text { 1,3,3-trimethyl-2- } \\
{[(1 E, 3 E, 5 E, 7 E, 9 E, 11 E, 13 E, 15 E, 17 E)-} \\
\text { 3,7,12,16-tetramethyl-18-(2,6,6- } \\
\text { trimethylcyclohexen-1-yl)octadeca- } \\
1,3,5,7,9,11,13,15,17-n o n a e n y l] \text { cyclohexene }\end{array}$ \\
\hline caramel & E150 & sugar & - \\
\hline
\end{tabular}

\section{Tested foods, beverages and special colours}

The tested foods, beverages and special colours are listed in Table 3. Food products as soups powder, yoghurt and sweet cream cheese are mixed in heated Milli-Q water. Mix fruit jam and the sparkling Mg tablet are mixed with Milli-Q water at room temperature. The beverages are used directly. Special colours are dissolved in Milli-Q water. 
Table 3. - Tested foods, beverages and special colours

\begin{tabular}{|c|c|c|c|}
\hline Name & E-number & Product & Manufacturer \\
\hline \multirow{3}{*}{$\begin{array}{c}\text { anthocyanin } \\
\mathrm{S}\end{array}$} & \multirow{3}{*}{ E163a } & $\begin{array}{l}\text { raspberry } \\
\text { yoghurt }\end{array}$ & $\begin{array}{c}\text { Zott SE\&Co.KG, } \\
\text { Mertingen, Germany }\end{array}$ \\
\hline & & $\begin{array}{l}\text { multivitamin } \\
\text { drink }\end{array}$ & $\begin{array}{l}\text { Rauch Fruchtsäfte } \\
\text { GmbH, Rankweil, } \\
\text { Austria }\end{array}$ \\
\hline & & mix fruit jam & $\begin{array}{l}\text { Hamé, Hungaria Ltd., } \\
\text { Komárom, Hungary }\end{array}$ \\
\hline \multirow[b]{3}{*}{$\beta$-carotene } & \multirow[b]{3}{*}{ E160a } & $\begin{array}{l}\text { vanilla milk } \\
\text { drink }\end{array}$ & $\begin{array}{l}\text { Mizo, Szeged, } \\
\text { Hungary }\end{array}$ \\
\hline & & $\begin{array}{l}\text { sweet cream } \\
\text { cheese }\left(\mathrm{Mizo}^{1},\right. \\
\left.\mathrm{Mia}^{2}\right)\end{array}$ & $\begin{array}{c}{ }^{1} \text { Mizo, Szeged, } \\
\text { Hungary } \\
{ }^{2} \text { Friesland-Campina } \\
\text { Hungária Ltd., } \\
\text { Budapest, Hungary }\end{array}$ \\
\hline & & $\begin{array}{l}\text { orange drink } \\
\quad \text { Fanta }^{1} \\
\text { Schweppes }^{2} \\
\left.\text { McDonalds }^{1}\right)\end{array}$ & $\begin{array}{c}\text { Coca-Cola } \\
\text { Magyarország, } \\
\text { Dunaharaszti, } \\
\text { Hungary } \\
\text { ²PEPSICO - Fóvárosi } \\
\text { Ásványvíz és } \\
\text { Üdítőipari Ltd., } \\
\text { Budapest, Hungary }\end{array}$ \\
\hline $\begin{array}{c}\beta \text {-carotene, } \\
\text { betanin and } \\
\text { anthocyanin } \\
\mathrm{s}\end{array}$ & E160a, E162, E163a & $\begin{array}{l}\text { sour cherry } \\
\text { yoghurt }\end{array}$ & $\begin{array}{c}\text { Bauer, J. Bauer } \\
\text { GmbH \& Co. KG, } \\
\text { Wasserburg am Inn, } \\
\text { Germany }\end{array}$ \\
\hline curcumin & E100 & $\begin{array}{l}\text { Knorr instant } \\
\text { soups }\end{array}$ & $\begin{array}{l}\text { Unilever } \\
\text { Magyarország Ltd., } \\
\text { Budapest, Hungary }\end{array}$ \\
\hline $\begin{array}{c}\text { curcumin } \\
\text { and caramel }\end{array}$ & E100, E150 & $\begin{array}{l}\text { Maggi instant } \\
\text { soup }\end{array}$ & $\begin{array}{c}\text { Nestlé Magyarország, } \\
\text { Budapest, Hungary }\end{array}$ \\
\hline \multirow[t]{2}{*}{$\begin{array}{l}\text { sodium } \\
\text { riboflavin 5' } \\
\text { phosphate } \\
\end{array}$} & E106 & $\begin{array}{l}\text { Mg sparking } \\
\text { tablet }\end{array}$ & $\begin{array}{l}\text { CO-OP HUNGARY } \\
\text { Ltd., Budapest } \\
\text { Hungary }\end{array}$ \\
\hline & Chemical name & & \\
\hline $\begin{array}{l}\text { quinolone } \\
\text { yellow }\end{array}$ & $\begin{array}{l}\text { sodium 2-(1,3-dioxoindan-2- } \\
\text { yl)quinolinedisulfonate }\end{array}$ & $\begin{array}{l}\text { Eastern egg } \\
\text { colour }\end{array}$ & $\begin{array}{l}\text { Microse Ltd., Érd, } \\
\text { Hungary }\end{array}$ \\
\hline $\begin{array}{c}\text { sunset } \\
\text { yellow FCF }\end{array}$ & $\begin{array}{c}\text { disodium salt of 6-hydroxy-5-[(4- } \\
\text { sulfophenyl)azo]-2- } \\
\text { naphthalenesulfonic acid }\end{array}$ & $\begin{array}{l}\text { Eastern egg } \\
\text { colour }\end{array}$ & $\begin{array}{l}\text { Microse Ltd., Érd, } \\
\text { Hungary }\end{array}$ \\
\hline $\begin{array}{l}\text { tropaeolin } \\
\text { OO }\end{array}$ & $\begin{array}{l}\text { 4-(4-anilinophenylazo)benzene } \\
\text { sulfonic acid sodium salt }\end{array}$ & & $\begin{array}{l}\text { Reachim Ltd., } \\
\text { Moscow, Russia }\end{array}$ \\
\hline $\begin{array}{c}\text { methylorang } \\
\mathrm{e}\end{array}$ & $\begin{array}{l}\text { sodium } 4-[(4- \\
\text { dimethylamino)phenyldiazenyl }] b \\
\text { enzenesulfonate }\end{array}$ & & $\begin{array}{l}\text { Reachim Ltd., } \\
\text { Moscow, Russia }\end{array}$ \\
\hline azure II & $\begin{array}{c}N^{\prime}, N^{\prime} \text {-dimethylphenothiazin-5- } \\
\text { ium-3,7-diamine chloride }\end{array}$ & & $\begin{array}{l}\text { Reachim Ltd., } \\
\text { Moscow, Russia }\end{array}$ \\
\hline
\end{tabular}




\begin{tabular}{|c|c|c|c|}
\hline $\begin{array}{c}\text { acridine } \\
\text { orange }\end{array}$ & $\begin{array}{c}N, N, N^{\prime}, N^{\prime} \text {-Tetramethylacridine- } \\
\text { 3,6-diamine }\end{array}$ & $\begin{array}{c}\text { Reachim Ltd., } \\
\text { Moscow, Russia }\end{array}$ \\
\hline
\end{tabular}

Visual and UV-VIS colour determination of the food colour modified cellophane

112 Each of the test strips is immersed into different solutions prepared from food and beverages 113 for a period between $10 \mathrm{~min}$ and $24 \mathrm{~h}$ (to monitor the timing effect). Fifty parallel 114 measurements of each sample are performed. The test strips are washed with Milli-Q water 115 and dried at room temperature using blotting paper. The characterisation is done by an UVVIS spectrophotometer between 300-800 nm (HP 8452A, Hewlett Packard, Palo Alto California, USA), the stretched test strip is placed perpendicular to the light path.

\section{"Wash-out" test}

The coloured test strips are immersed into Milli-Q water for $24 \mathrm{~h}$ and dried at room temperature using blotting paper.

\section{Alkaline test solution}

Alkaline solution of 1 mol.L ${ }^{-1} \mathrm{NaHCO}_{3}$ (Sigma-Aldrich) is used.

\section{RESULTS AND DISCUSSION}

\section{Quick test method and primary food colour test}

The basic principle of the quick colour food system is built on a portable, eco-friendly and economical spectrophotometer, connected to a laptop or smartphone, running a program using a spectra database. In developing countries, where the access to equipment is limited, conclusion can be done based on the visual checking of the coloured test strips. 1964), so coloured alcoholic solutions will not colour cellophane). 
The colouring effect of commercially available primary food colours on cellophane test strip is investigated. Short (10 $\mathrm{min})$ and long $(24 \mathrm{~h})$ immersion times are used. After $10 \mathrm{~min}$ the cellophane test strips become coloured in the case of the yellow, red and green dyes. The blue dye does not have effect on the test band colour. After $24 \mathrm{~h}$ immersion the patent blue $\mathrm{V}$ colours the test strip, too (Fig. 1).

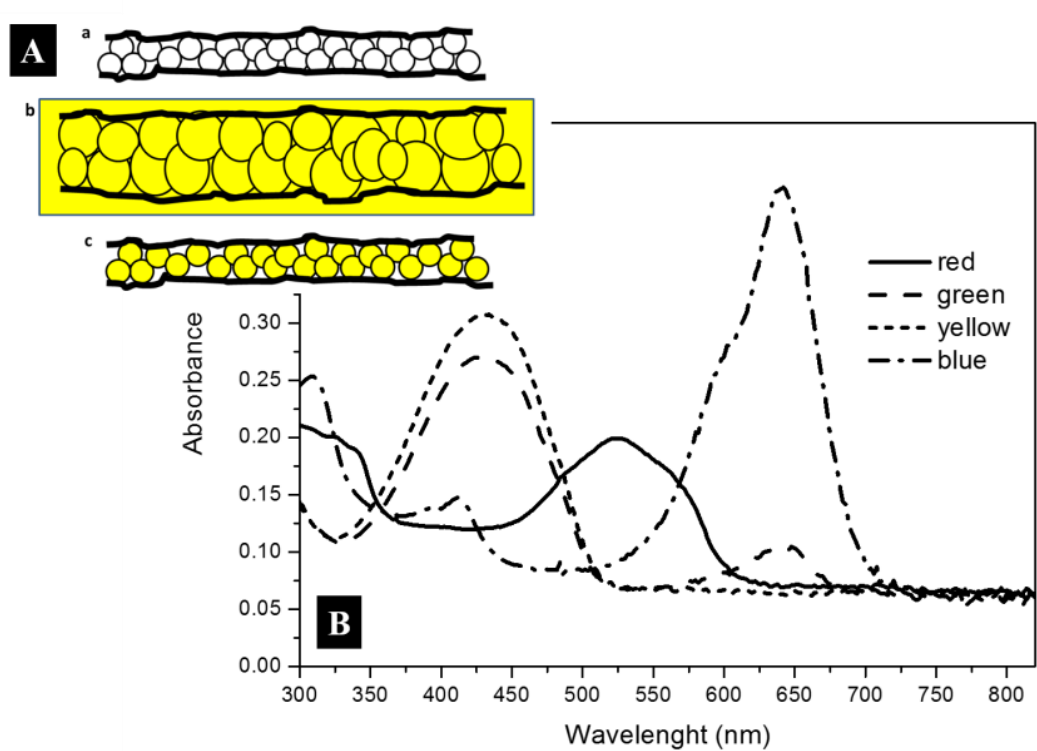

Wavelenght $(\mathrm{nm})$

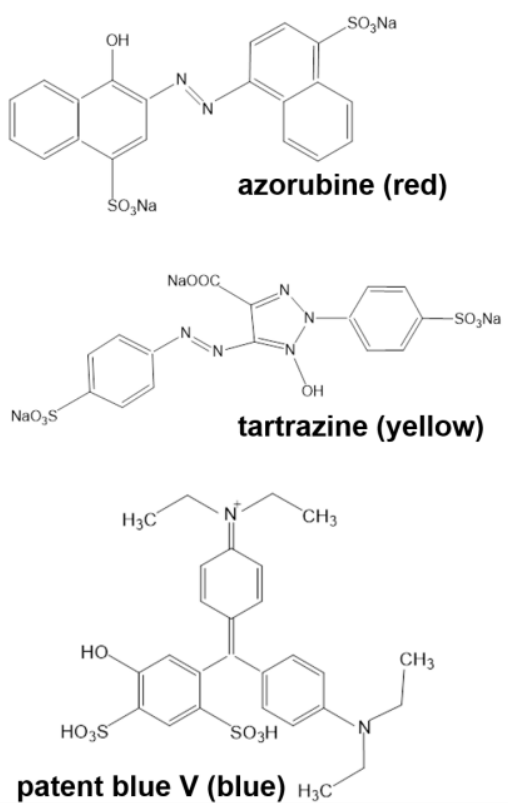

Figure 1. - Primary food colour test: schematic model (A) of the cellophane colouring mechanism ( $a$-cellophane, $b$-immersion into a dye, $c$-coloured cellophane); absorption spectrum $(B)$ of the coloured cellophane with red (azorubine), yellow (tartrazine), blue (patent blue $V$ ) and green (tartrazine \& patent blue $V$ ) primary food colours (immersion time $24 h)$

The colouring effect is based on physisorption of the dye molecules in the swelled cellophane capillaries (Fig. 1Ab and 1Ac). Authors conjecture that the differences in the chemical structure of the dyes are responsible for this time shift in the colouring effect: the azo-dyes (tartrazine, azorubine), due to their aromatic azo-group coloured almost instantly the 
152

153

154

155

156

157

cellophane, since the patent blue $\mathrm{V}$, which has no aromatic azo-group only aromatic groups need longer time to bind physically to the cellophane.

\section{Selectivity of the cellophane test strip}

\section{Natural vs. synthetic colours}

Natural colours are compared to synthetic colours. At the red-colour test (Fig. 2) the extract of beetroot (betanin) is compared to azorubine.
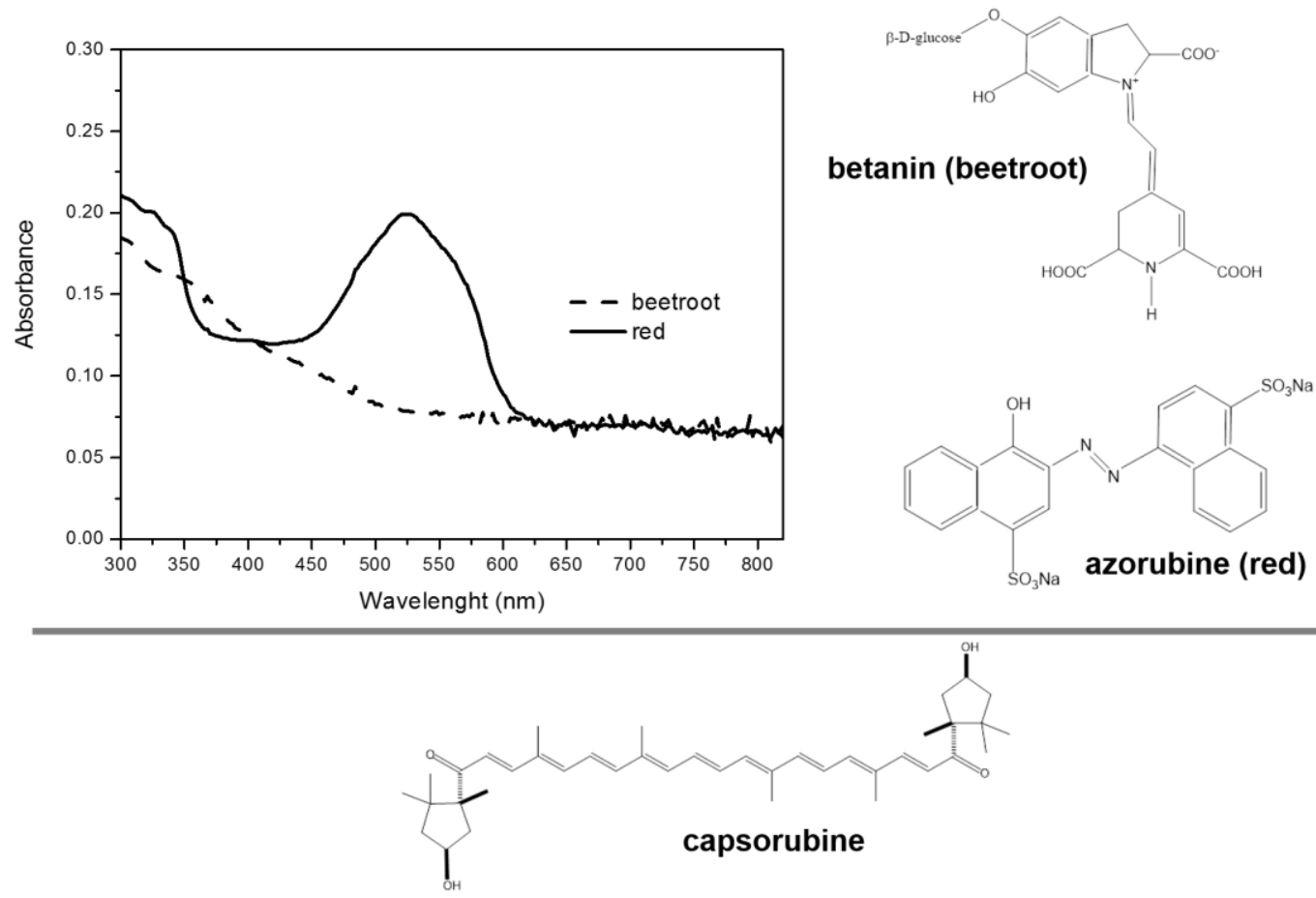

Figure 2. - Red colour test: absorption spectrum of the red coloured cellophane using natural colour extracted from beetroot (betanin) and primary red food colour (azorubine); chemical structure of capsorubin

The test strip immersed in beetroot extract remains uncoloured, contrary to that immersed in azorubine solution. The differences might originate from the presence of the electron resonance effect in the aromatic azo-groups of azorubine. The same non-colouring effect is observed in the case of capsorubin, probably caused by its non-aromatic structure. 
167 To prove our hypothesis, natural food colours with aromatic groups are tested. Spectra of curcumin and tartrazine are presented on Fig. 3. After $24 \mathrm{~h}$ of immersion both dyes colour the test strip.
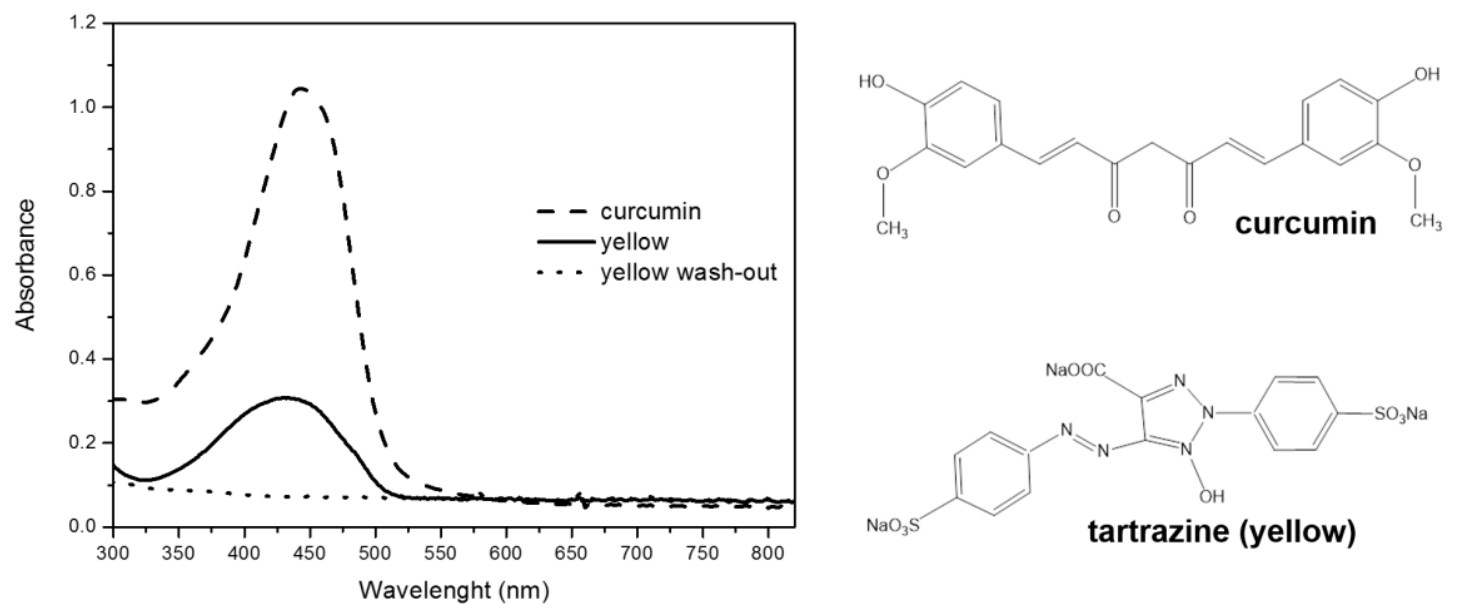

171

Figure 3. - Yellow colour test: absorption spectrum of the yellow coloured cellophane using natural yellow colour (curcumin) and the primary food colour (tartrazine)

To understand the colouring process of curcumin, both test strips are immersed into water for $24 \mathrm{~h}$ (wash-out test). It is found that the tartrazine coloured test strip lost its colour (Fig. 3 177 yellow wash-out), while the curcumin retained its yellow colour. In the case of tartrazine the wash-out process of the coloured test strip strengthens our conjecture that most food colours are physisorbed in the capillaries of the cellophane. Curcumin, in contrast, strongly binds to the cellophane with a largely preserved molecular structure. This is indicated by its retained indicator property (Dandekara et al. 2010) (in basic solution the colour of curcumin turns to red). Indeed, the colour of the yellow test strip - after wash-out test - turns red in a few seconds in $\mathrm{NaHCO}_{3}$ solution. 


\section{Real test with foods, drinks and special colours}

185

186

187

The presence of the synthetic food colours in any liquid product (beverages, soups and milk products) can be proved using our newly developed quick test. The dyes obtained from natural sources are used as standards (carrot: $\beta$-carotene, caramelised sugar: caramel).

First instant soups are tested and the absorbance spectra are compared to absorption spectrum of curcumin (Fig. 4). Based on the ingredients listed, the Knorr powder is coloured by curcumin and the Maggi soup by curcumin and caramel.
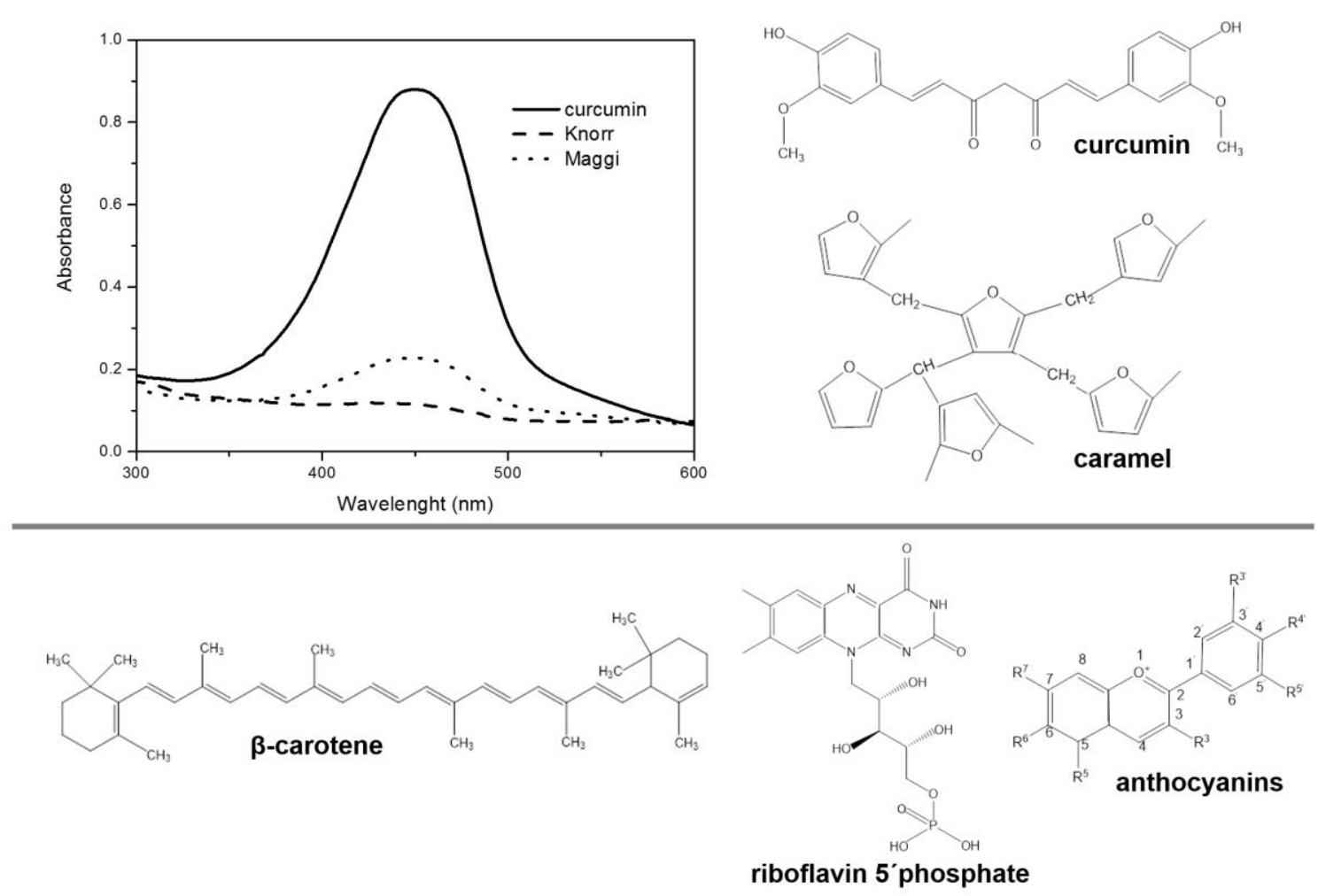

Figure 4. - Real food tests: absorbance spectrum of instant soups and curcumin; chemical structure of the dyes which has no colouring effect on cellophane test strip: caramel, $\beta$ carotene, riboflavin 5' phosphate, anthocyanins

In both cases only one peak can be seen, and this corresponds to curcumin absorbance. Following to our conjecture, due to its structure caramel (no aromatic or aromatic azo-groups) would not colour the cellophane test strip, so on the absorption spectrum only the peak 
corresponding to curcumin is visible. The wash-out test (the test strip remain yellowish) and the treatment by $\mathrm{NaHCO}_{3}$ (the test strip changes its colour to red) confirm strong bonding between curcumin and the cellophane test strip with a largely intact molecular structure.

$\beta$-carotene is one of the most frequently used natural colorant. In the first step we have extracted it from carrot. The cellophane test strip is negative for $\beta$-carotene in accordance with its structure. To further prove our method, orange drinks, milk products (Table 3.) are tested. Anthocyanins (tested in yoghurt products, mix fruit jam and multivitamin drink) and sodium riboflavin 5' phosphate (Mg sparking tablet) are considered healthy natural colorants. In all cases ( $\beta$-carotene, sodium riboflavin 5' phosphate, anthocyanins) no colouring effect is observed due to the absence of the typical resonance effect existing in the molecules of the synthetic dyes.

Some special synthetic dyes - used for Easter egg colouring - are also tested (Fig. 5).
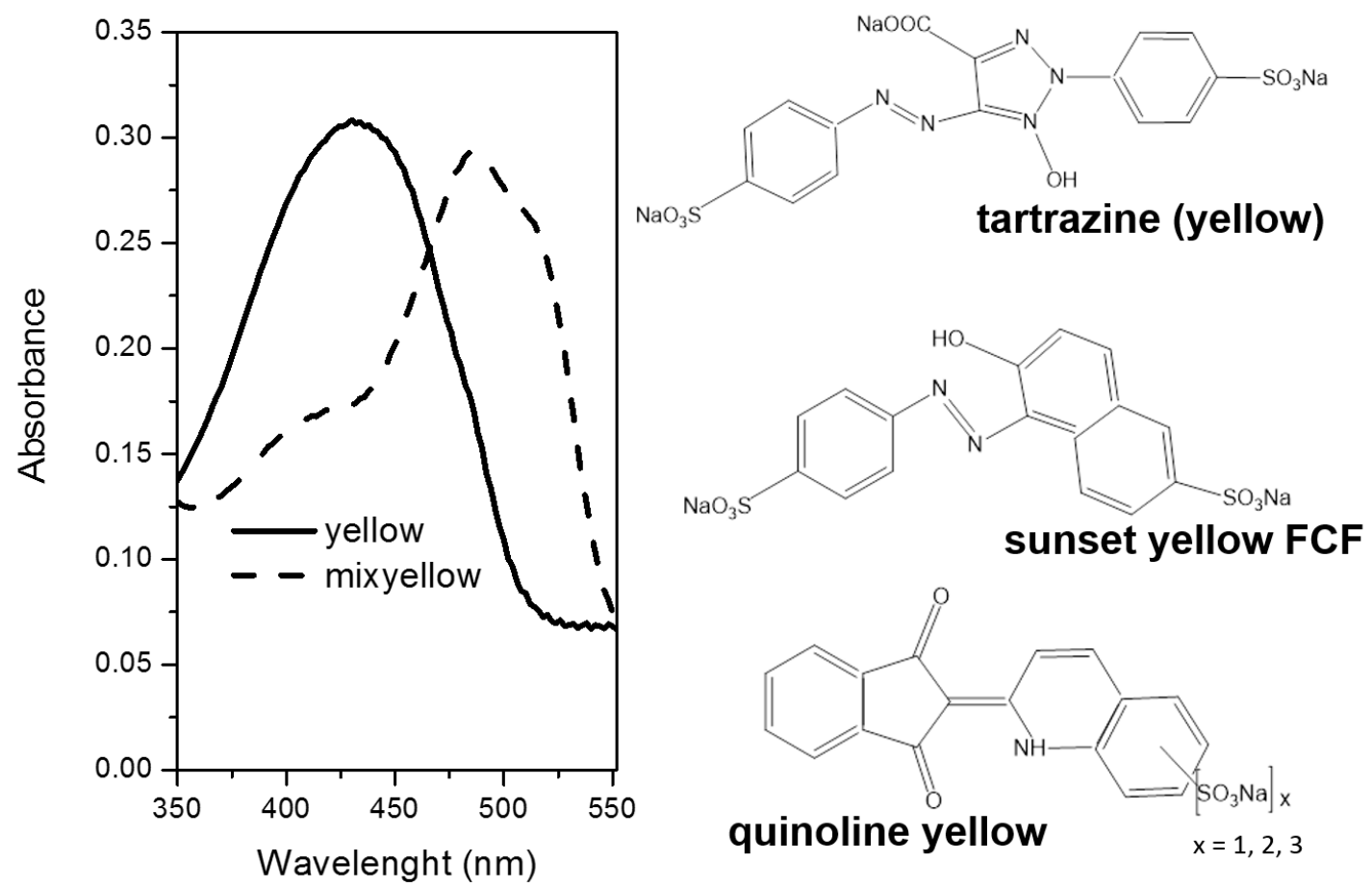

Figure 5. - The absorbance spectrum and molecular structure of the tartrazine (yellow) compared to yellow egg colour (mixyellow: sunset yellow FCF and quinoline yellow) 
214 Based on the listed ingredients the investigated yellow egg colour is a mixture of sunset 215 yellow FCF and quinoline yellow. The absorbance spectrum of the mixture (mixyellow) and 216 tartrazine (yellow) is compared. The mixture shows two peaks, one on the left corresponds to

217 sunset yellow (it's an azo-dye with similar structure to tartrazine) and the other correspond to 218 quinoline yellow. This experiment also shows that food colours, thanks to the different 219 structures of the dyes molecules can be distinguished from each other also within the same 220 colour-range.

222 Expanding the application of the quick test beyond food industry

223 Quick test method might be used for dyes beyond the food industry (Fig. 6A), colours 224 containing azo-groups, tropaeolin OO and the methylorange are tested. Both azo-dyes behave 225 like azo-food dyes (such as tartrazine). The wash-out process confirms the physisorption. 

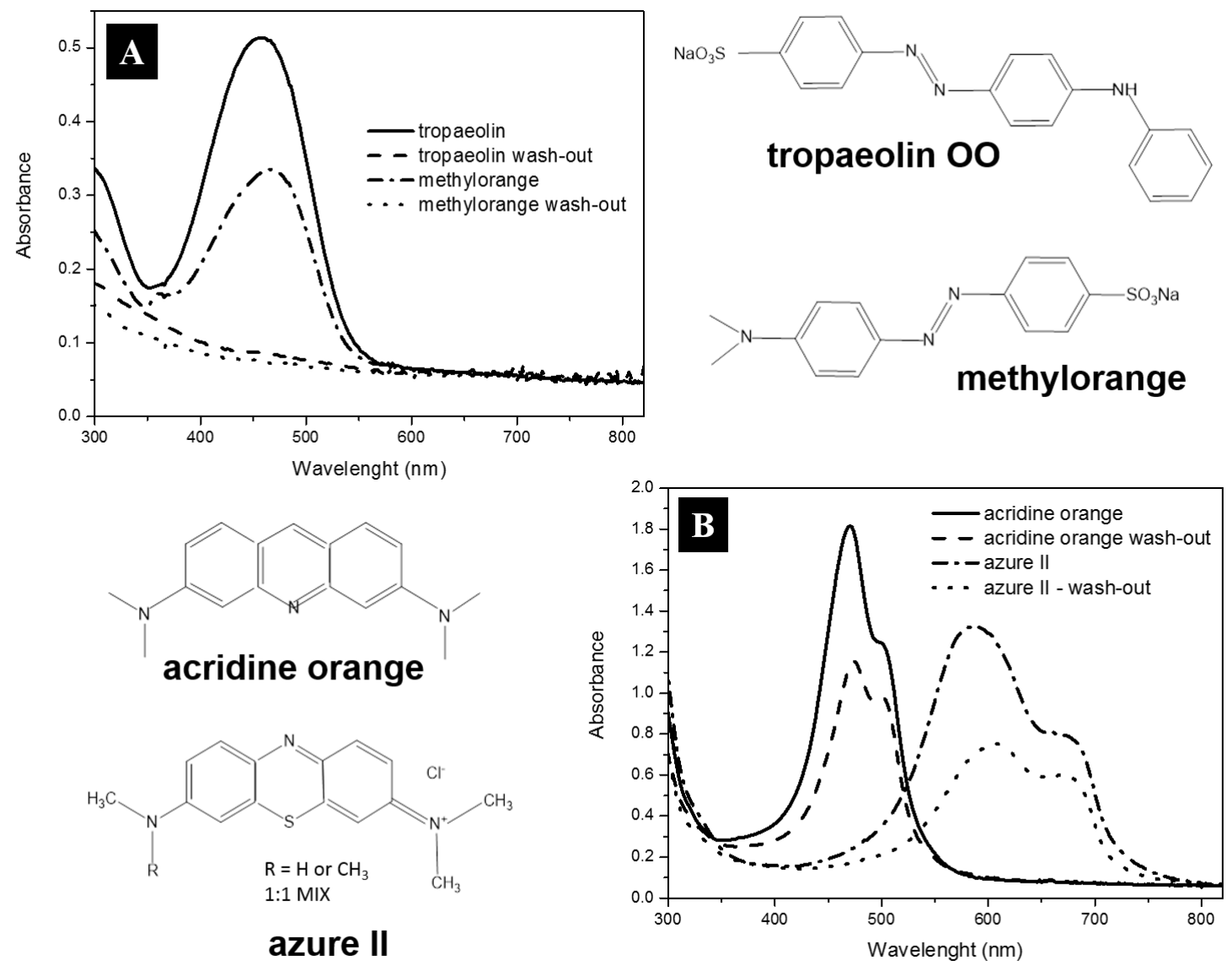

Figure 6. - Expanded application of the quick test: absorbance spectra (A) of tropaeolin $O O$ and methylorange vs. the wash-out test strip spectra; absorbance spectra (B) of acridine orange and azure II vs. the wash-out test strip spectra

At the same time, in the case of acridine orange and azure II a stronger interaction between the molecules of dyes and cellophane is observed as result of the wash-out test (Fig. 6B), the effect can be explained by the electron structure of the three heterocyclic rings containing $\mathrm{S}$ and $\mathrm{N}$.

\section{CONCLUSION}

A new, qualitative, quick food test method - highly sensitive to synthetic dyes - is presented based on the food dyes colouring effect of the cellophane test strip. The method is useful to 
expose food products adulterated with synthetic colorants or for in situ tests at catering and mobile vendors.

241 Theoretical conjectures pertaining to molecular structure are confirmed in all performed experiments: test strip is coloured in case when molecule of the dye contain aromatic azogroups (e. g. tartrazine, azorubine) or aromatic groups (e. g. patent blue V, curcumin) with resonance effect inside the molecule; test strip is left uncoloured by dye without aromatic azogroups (e. g. all natural colours), aromatic groups (e. g. capsorubin, caramel) and those which contain aromatic groups but without resonance effect inside molecule (e. g. betanin, riboflavin). Natural and primarily food dyes from same colour-range are compared; and application of the test is expanded to azo- and aromatic dyes beyond food industry.

\section{REFERENCES}

Aguilar F (2009-1) Scientific Opinion of the Panel on Food Additives, Flavourings, Processing Aids and Food Contact Materials (AFC). The EFSA Journal 660:1-54

Aguilar F (2009-2) Scientific Statement of the Panel on Food Additives and Nutrient Sources added to Food. The EFSA Journal 1188: 1-7

Beach RH, Van Houtven GL, Buckley MC, Depro BM (2000) Economic Analysis of Air Pollution Regulations: Miscellaneous Cellulose Manufacturing Industry/Industry Profile. RTI Project 7647-001-011

Cañas A, Ariza MJ, Benavente J (2002) A Comparison of Electrochemical and Electrokinetic Parameters Determined for Cellophane Membranes in Contact with $\mathrm{NaCl}$ and $\mathrm{NaNO}_{3}$ Solutions. Journal of Colloid and Interface Science 246:150-156

Dandekara P, Dhumalb R, Jaina R, Tiwarib D, Vanageb G, Patravale V (2010) Toxicological evaluation of $\mathrm{pH}$-sensitive nanoparticles of curcumin: Acute, sub-acute and genotoxicity studies. Food and Chemical Toxicology 48:2073-2089 
Desobry SA, Netto FM, Labuza TP (1998) Preservation of $\beta$-Carotene from Carrots. Critical Reviews in Food Science and Nutrition 38:381-396

European Commission - EC (2013) Analysis of needs in post-market monitoring of food additives and preparatory work for future projects in this field. Supporting Publications 2013:EN-419

Evans CC (1964) Characterization of cellophane as an ionic barrier. Chemistry Research Department, U.S. Naval Ordnance Laboratory, Maryland, US Patent AD 437997

Food Safety and Standards Authority of India - FSSAI (2012) Manual of methods of analysis of foods and food additives, Ministry of Health and Welfare, Government of India, New Delhi, 89-112

Food Standards Australia New Zealand - FSANZ (2008) Supplementary report to the 2008 Survey of added colours in foods available in Australia

Jiang B, Liu Y, Bhandari B, Zhou W (2008) Impact of Caramelization on the Glass Transition Temperature of Several Caramelized Sugars. Part I: Chemical Analyses. J. Agric. Food Chem. $56: 5138-5147$

Komissarchik S, Nyanikova G (2014) Test systems and a method for express detection of synthetic food dyes in drinks. LWT - Food Science and Technology, doi:10.1016/j.lwt.2014.03.038

Kucharska M, Grabka J (2010) A review of chromatographic methods for determination of synthetic food dyes. Talanta 80:1045-1051

Laity PR, Glover PM, Godward J, McDonald PJ, Hay JN (2000) Structural studies and diffusion measurements of water-swollen cellophane by NMR imaging. Cellulose 7:227-246

Pourrat H, Lejeune B, Regerat F, Pourrat A (1983) Purification of red beetroot dye by fermentation. Biotechnology Letters 5: 381-384 
303 Rey AI, Hopia A, Kivikari R, Kahkonen M (2005) Use of natural food/plant extracts:

304 cloudberry (Rubus Chamaemorus), beetroot (Beta Vulgaris "Vulgaris") or willow herb 305 (Epilobium angustifolium) to reduce lipid oxidation of cooked pork patties LWT - Food 306 Science and Technology, 38:363-370

307

308 Shen Y, Zhang X, Prinyawiwatkul W, Xu Z (2014) Simultaneous determination of red and 309 yellow artificial food colourants and carotenoid pigments in food products. Food Chemistry $310 \quad 157: 553-558$

312 Tomé LC, Goncalves CMB, Boaventura M, Brandão L, Mendes AM, Silvestre AJD, Neto 313 CP, Gandini A, Freire CSR, Marrucho IM (2011) Preparation and evaluation of the barrier 314 properties of cellophane membranes modified with fatty acid. Carbohydrate Polymers $315 \quad 83: 836-842$

317 Yoshioka N, Ichihashi K (2008) Determination of 40 synthetic food colours in drinks and 318 candies by high-performance liquid chromatography using a short column with photodiode 319 array detection. Talanta 74:1408-1413 